\title{
Profusão da morte e liberdade formal no interior de necrópoles brasileiras
}

Profusion of death and formal freedom in Brazilian necropolises

\section{Leonardo Oliveira}

Arquiteto, mestre pela FAU/UnB, doutorando em arquitetura pela Universidade Federal do Rio Grande do Sul, tradutor entre as línguas portuguesa, inglesa e espanhola.

\section{Resumo}

Em sua obra Cidades dos vivos (2002), Renato Cymbalista conclui que a arquitetura tumular paulista, até 1970 , não foi elaborada de modo completamente desvinculado de representações da elite da época. Parcialmente livres para conceber a forma final dos túmulos, as "equipes" responsáveis pelos projetos a família do morto e o pedreiro do cemitério conformavam paisagens heterogêneas e fragmentadas: uma autêntica profusão de formas, materiais e cores, em que as classes sociais menos abastadas procuravam se espelhar na alta sociedade. Tendo a obra de Cymbalista como principal referência, o presente artigo se propõe perscrutar até que ponto a arquitetura tumular brasileira foi capaz de produzir um resultado formal livre de imposições externas, isto é, uma arquitetura tumular própria e "autenticamente" nacional.

Palavras chave: arquitetura funerária; cemitérios; morfologia tumular; liberdade formal.

\section{Abstract}

In his book Cidades dos vivos (2002), Renato Cymbalista concludes that São Paulo's tomb architecture, until 1970, was not elaborated in a way completely unrelated to the elite's representations of that time. Partially free to conceive the final shape of the tombs, the "teams" responsible for the projects - the dead's family and the cemetery mason - built heterogeneous and fragmented landscapes: an authentic profusion of forms, materials, and colors, where least privileged people sought to mirror themselves in the high society. Having Cymbalista's book as the main reference, the present article aims to examine, in general, the extent to which the Brazilian tomb architecture was able to produce a formal result free of external impositions - its own and "autentically" national tomb architecture.

Keywords: funerary architecture.; cemeteries; tomb morphology; formal freedom. 


\author{
"[... até que ponto as representações da morte são mais um dos privilégios das elites, \\ deixando para o restante da sociedade apenas a possibilidade de reagir a essas \\ representações vindas de cima?"
}

\section{Introdução}

Porvolta de 1850 surgiu no Brasil uma nova tipologia arquitetônica: o cemitério chamado de "Campo Santo". Os espaços da morte, que emergiram entre a segunda metade do século XIX e o início do século XX, foram respaldados em uma nova atitude do indivíduo frente à finitude humana, originada da exaltação da própria individualidade. Este modo de perceber e lidar com a morte sofreu influência do Romantismo e do Racionalismo lluminista ${ }^{2}$, quando homens como Rousseau, Voltaire e D'Alembert propugnaram ideias de progresso e razão baseadas no tripé Liberté, Egalité, Fraternités.

Morfologicamente, os primeiros cemitérios brasileiros foram baseados em necrópoles estrangeiras, sobretudo francesas e italianas e, de modo análogo ao que ocorria em tais necrópoles, utilizaram elementos arquitetônicos a fim de evidenciar CYMBALISTA, 2002, p. 20.

CITELLI, 1993, p. 92.

Arte e sociedade nos cemitérios brasileiros, 1972, p. 281.

Cidades dos vivos: arquitetura e atitudes perante a morte nos cemitérios do Estado de São Paulo, 2002, p. 17.

CYMBALISTA, 2002, p. 71.

MOTTA, 2009, p. 85.

Em solo brasileiro, como aponta Cymbalista, é necessário considerar a historicidade específica das necrópoles locais, que se distinguem das europeias por terem sido respaldadas em transformações sociais particulares ${ }^{5}$. Talvez não seja possível, portanto, afirmar que o Brasil detenha uma estética tumular própria, isto é, um padrão a ser reconhecido em elementos funerários de espaços diversos. imposições sanitárias, legais e políticas, que foram arrastadas durante um longo embate até que os mortos conquistassem o Campo Santo. Faltava, no entanto, que estes novos espaços adquirissem preenchida pela arquitetura tumular ao gosto estrangeiro, respaldada no desejo de distinção social ${ }^{6}$. A forma final dos túmulos nesses espaços partiu, portanto, de imposições culturais, estéticas e econômicas, inclusive entre os menos abastados que, posteriormente, tentariam reproduzir túmulos da elite talvez na esperança de se assemelharem a ela após a morte.

\section{O anseio pela exaltação da própria individualidade nas primeiras necrópoles brasileiras}

Os primeiros cemitérios brasileiros sofreram influência significativa da estética tumular estrangeira, sobretudo europeia, por meio da profusão de alegorias e da estatuária representada, em geral, por anjos e figuras femininas ${ }^{7}$. Os espaços da morte gradativamente conformaram paisagens melancólicas e dramáticas, cenários condizentes com os preceitos do movimento romântico do período:

\section{O romantismo traz a complacência diante da morte, mas também traz, de certa forma, a ansiedade sobre suas próprias memórias não poderem morrer, ultrapassando a morte definitiva, expressando uma nova forma materialista de respeito pela morte que garantiu o sucesso de venda de lotes funerários perpétuos e monumentos projetados para preservar - e exaltar - a memória do morto ${ }^{8}$}

As primeiras necrópoles paulistas surgiram a partir de legitimidade simbólica e estética, lacuna que foi
Embora em âmbito literário o movimento romântico tenha rompido laços de dependência com a colônia portuguesa e admitido comportamentos fundamentados na exaltação de elementos tipicamente nacionais, sobretudo entre a alcunhada primeira geração romântica ${ }^{9}$, a estética tumular brasileira do século XIX importou preferências e gostos estrangeiros, conformando reproduções praticamente idênticas a cemitérios franceses e italianos, cuja arte tumular era também elaborada por indivíduos europeus.

Se, no âmbito da literatura, o Romantismo preocupouse em conceber um "perfil nacional suficientemente forte para provar a viabilidade do filho insurgente 
frente aos atentos olhos europeus", com relação aos espaços da morte ocorreu o contrário; uma vez que, no Brasil, não havia precedentes desta tipologia, provavelmente não havia alternativa senão a cópia de modelos consagrados. A morfologia espacial, no entanto, não foi o único elemento incorporado pelos primeiros cemitérios brasileiros; do mesmo modo como ocorria em necrópoles estrangeiras, a imponência dos túmulos passou a assumir caráter diretamente proporcional ao status do morto em vida.

O romantismo nasceu, no Brasil, marcado por essas preocupações e acabou funcionando um pouco, principalmente junto aos autores da primeira geração, como uma espécie de frente para afirmar a nacionalidade [...] particularmente no caso da literatura [...]. Mas onde estavam tais referências: Evidentemente não nas instituições, novas e frágeis, em processo de formação, inconsistentes, portanto, para expressarem o vigor da novidade ${ }^{10}$.
A pintura de Arnold Böcklin ilustra a paisagem fúnebre característica de necrópoles europeias, que migrou para o Brasil no século XIX. Na obra, Jung chama atenção para a figura de branco, que lembra um padre e que direciona o barco com o esquife rumo a uma ilha ${ }^{12}$. Motta, por sua vez, prossegue com a descrição: "Em mar de águas calmas, e sob um céu de carregadas nuvens, o barco segue em direção a uma pequena ilha formada por grandes blocos de rochedos irregulares, conduzindo o morto para sua derradeira morada ${ }^{13}$ ".

O simbolismo presente na obra de Böcklin fez-se evidente nos espaços da morte, que objetivaram, por meio de múltiplas alegorias, estabelecer diálogos com os vivos. Diversos autores mencionam tal diálogo entre vida e morte nos cemitérios, que seria possibilitado pela estatuária e outros símbolos tumulares. À época do movimento romântico, tornaram-se fenômenos indissolúveis o da morte e seus desdobramentos romanticizados uma vez que, segundo Kovács, os indivíduos literalmente se matavam por amor,
10

Ibidem, p. 47

11

MOTTA, 2009, p. 45.

$12^{\star} 0$ homem e seus símbolos [1964], 2002, p. 279.

13

À flor da pedra: formas tumulares e processos sociais nos cemitérios brasileiros, 2009, p. 45-8.

FIGURA 01: "A ilha dos mortos" (1883), de Arnold Böcklin, ilustra a paisagem romântica fixada pelo gosto contemplativo de inspiração fúnebre ${ }^{11}$ que caracterizaria os primeiros espaços da morte brasileiros. Óleo sobre tela. Leipzig, Museum der BildendenKunste. FONTE: JUNG [1964], 2002, p. 279. 


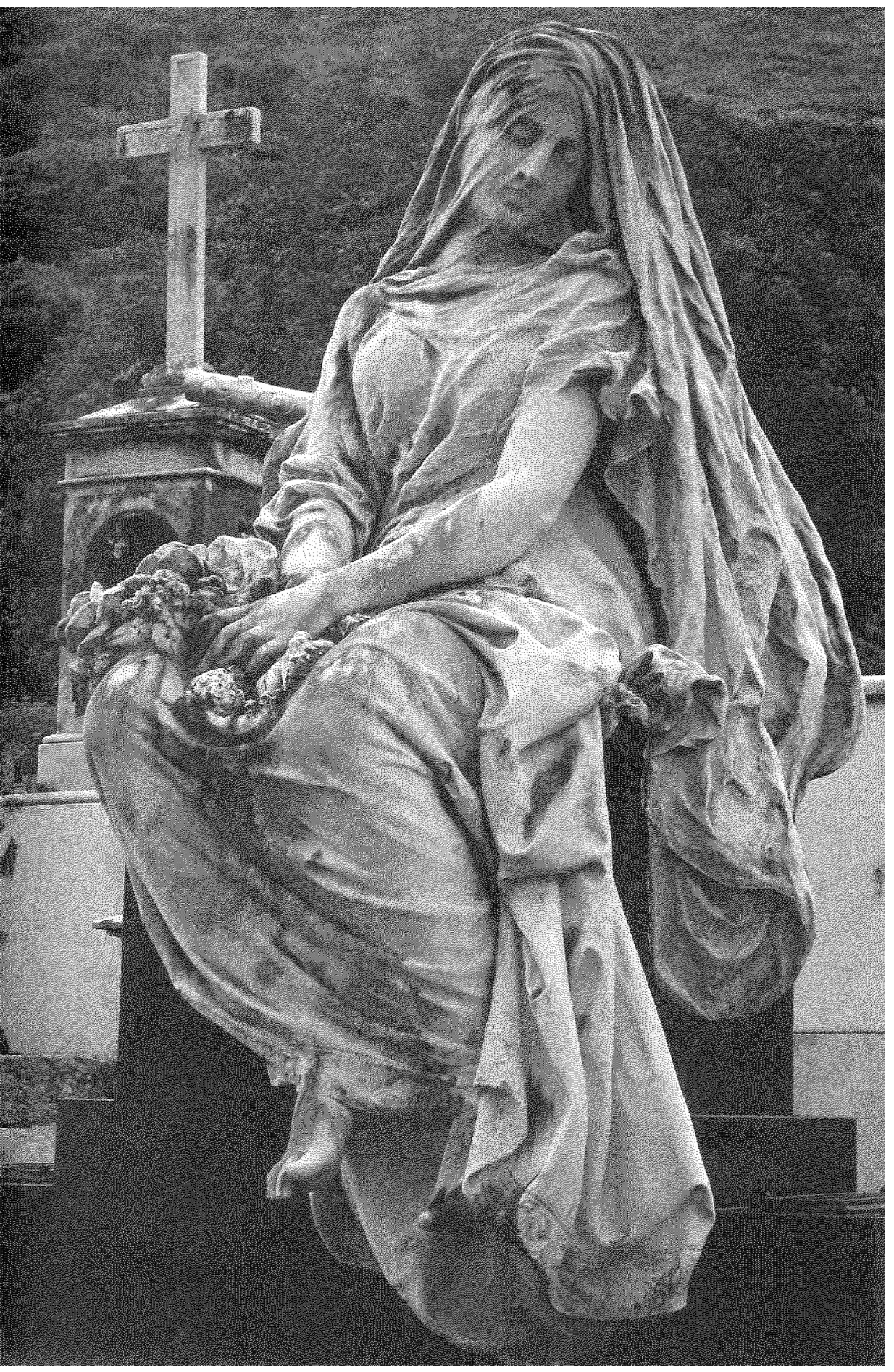

FIGURA 02: Escultura de autor não identificado. Cemitério de São João Batista, Rio de Janeiro. FONTE: MOTTA, 2009, p. 87. o que deu origem à expressão "morrer de amor". [...] o pico da vida ronda a morte. Os temas de [...] amor e morte fazem parte do enredo de óperas, poemas, romances e novelas e frequentemente a culminância destes enredos se configura com um grande amor e uma grande morte ${ }^{14}$.

De acordo com Amora, o movimento romântico brasileiro foi compreendido, em âmbito literário, entre os anos de 1830 e $1880^{15}$. Observam-se ainda em 1880 , no romantismo tardio de Azevedo, o caráter dramático e a presença de elementos fúnebres no momento da morte de Miguel, jovem incansavelmente apaixonado por Rosalina:

Miguel estava morto. Então, uma lágrima cristalina e santa, desprendendo-se do coração, rolou pura pelas faces da mulher. Chorou pela primeira vez! Aquela lágrima valia o poema inteiro de sua existência! Era o transunto do seu arrependimento! Era o perdão dos seus crimes! Chorou! Chorou uma lágrima de mulher, e por isso que vinha de Deus! Rosalina amou pela primeira vez aquele cadáver ${ }^{16}$.

Os primeiros cemitérios brasileiros conformam, portanto, segundo Motta, paisagens convidativas à meditação ${ }^{17}$. A presença de símbolos religiosos, expressiva de início, deu lugar à estatuária tumular já mencionada, cuja maioria representava cópias e reinterpretações de modelos consagrados em necrópoles como Staglieno (Gênova, Itália), PèreLachaise (Paris, França) e nos cemitérios monumental de Milão e central de Viena, entre outros da elite europeia ${ }^{18}$.

\section{Foi apenas no início do século XX que a morfologia tumular e suas alegorias começaram a adquirir uma dimensão mais laicizada, inclusive com especial ênfase nas figuras femininas. [...] Mediadores entre o céu e a terra, os anjos e arcanjos adultos ocupavam posição privilegiada na decoração tumular. [...] A metamorfose da figura do anjo em mulher foi outra característica da arte funerária desse período ${ }^{19}$.}

Estabelecia-se, desse modo, o diálogo entre elementos funerários e os visitantes desses espaços. A estatuária antropomórfica pretendia comunicar aos espectadores diversos estados de espírito: "ora anunciadores, ora tomados pelo êxtase, de alma 
exultante; ora repletos de esperança, de alma liberta; ora abatidos pela desolação, e outras intermitências da alma romântica":

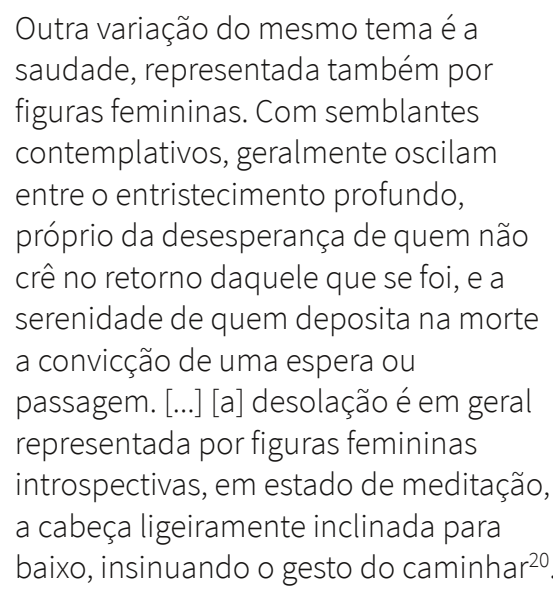

Segundo Valladares, o romantismo refletido em figuras e símbolos tumulares em cemitérios brasileiros deste período, embora denotem interesse na representação realística, não podem ser identificados pelos sinais eróticos que manifestariam posteriormente20. Devese apontar que, evidentemente, tal estatuária atuava também para explicitar o status do morto e era, em geral, encomendada diretamente da Europa:

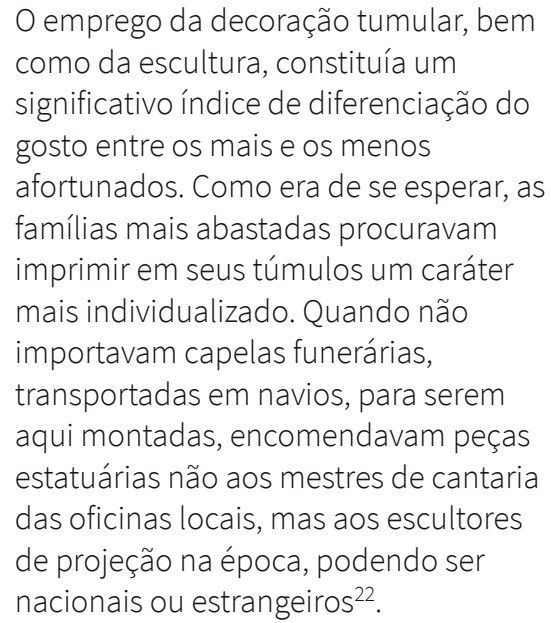

\section{Distinção e eternização do status social dos vivos}

Segundo Cymbalista, já eram evidentes no regulamento dos cemitérios de São Paulo, datado de 1856, os indícios da segregação socioespacial que se consolidaria posteriormente. 0 autor afirma que tal documento autorizava a edificação de monumentos funerários àqueles que podiam financiá-los, ao passo que vetava a monumentalização de sepulturas mais simples:
Art. $7^{\circ}$ : Nos terrenos concedidos por tempo de mais de 5 anos, é livre aos concessionários construir sepulturas, carneiros e túmulos, e colocar lápides e cenotáfios ou monumentos para sepultura, ou memória somente das pessoas declaradas no art. $6^{\circ} \S 4^{\circ}$, a plantar arvoredos e flores pela forma que mais Ihes convier [...]. Nas sepulturas rasas, por tempo de 3 anos, só poderão colocar-se pequenas grades de madeira, e uma cruz também de madeira, contanto que se acomodem por forma, que entre uma e outras sepulturas se guarde livre o intervalo de 2 palmos ${ }^{23}$.

Ainda conforme o autor, todas as necrópoles paulistas apresentavam configuração espacial semelhante na época, que demarcava territórios específicos para indigentes, de concessão gratuita, sempre em localizações menos visíveis e com restrições edilícias; por outro lado, o mesmo regulamento permitia a construção monumental em concessões pagas, que se faziam mais visíveis ${ }^{24}$. Nesse sentido, os elementos arquitetônicos assumiram papel de dispositivos de segregação, que evidenciaram e eternizaram disparidades sociais em espaços da morte:

$$
\begin{aligned}
& \text { os modos civilizados, ao mesmo tempo } \\
& \text { que lutavam contra os sepultamentos } \\
& \text { nas igrejas, preparavam } \\
& \text { cuidadosamente o terreno do cemitério } \\
& \text { para explicitar as distâncias sociais. [...] } \\
& \text { todas elas [as disposições territoriais da } \\
& \text { capital] apresentavam por um lado } \\
& \text { territórios específicos para indigentes, } \\
& \text { de concessão gratuita [...] [e] concessões } \\
& \text { pagas, cujas localizações de maior } \\
& \text { visibilidade vão ser disputadas pelas } \\
& \text { famílias mais poderosas das cidades }{ }^{25} \text {. }
\end{aligned}
$$

De acordo com Maranhão, a estratificação em práticas funerárias modernas evidencia tão somente a existência de uma sociedade de classes, o que faz da necrópole tradicional o mero reflexo da metrópole, com "avenidas, ruas, praças e jardins por onde os transeuntes podem circular orientados por placas indicativas; o habitat individual e coletivo, a administração local e capela"'.

A aspiração pelo reconhecimento após a morte enquanto membro de família importante deu espaço, posteriormente, ao desejo de distinção individual, que operaria nas novas necrópoles brasileiras de modo decisivo e originaria paisagens ainda mais
14

Morte e desenvolvimento humano, 1992, p. 6.

15

O Romantismo:

1833-1838/1878-1881 [1967], 1977, p. 17.

16 Uma lágrima de mulher [1880], 2004, p. 148.

17

À flor da pedra: formas tumulares e processos sociais nos cemitérios brasileiros, 2009, p. 49.

18

MOTTA, 2009, p. 88.

19

Idem, p. 85-6.

20

Ibidem, p. 86-9.

21

Arte e sociedade nos cemitérios brasileiros, 1972, p. 589.

22

MOTTA, 2009, p. 89.

23

Trecho extraído dos Annaes da Assembléia Legislativa Provincial de São Paulo (1856) por Cymbalista (2002, p. 79).

24 Cidades dos vivos: arquitetura e atitudes perante a morte nos cemitérios do Estado de São Paulo, 2002, p. 79.

\section{5}

CYMBALISTA, 2002, p. 79.

26

O que é morte [1985], 1998, p. 36. 
Cidades dos vivos: arquitetura e atitudes perante a morte nos cemitérios do Estado de São Paulo, 2002, p. 78.

VALLADARES, 1972, apud CYMBALISTA, 2002, p. 78.

À flor da pedra: formas tumulares e processos sociais nos cemitérios brasileiros, 2009, p. 90. discrepantes, ora esteticamente enriquecidas e permeadas de elementos ostensivos (em áreas destinadas à elite), ora simples, regradas e homogêneas (em áreas destinadas aos menos abastados).

Segundo Cymbalista, o culto à ideia de que o indivíduo existe e atua dentro da sociedade conforme atributos próprios e se distingue positivamente da sociedade circundante amadureceu de modo concomitante aos novos costumes fúnebres da modernidade paulista ${ }^{27}$ :
A simplicidade dos padrões tradicionais e primitivos continuou caracterizando a sepultura coletiva enquanto surgiu e se desenvolveu, espantosamente, o fausto e a arrogância tumulária individualista. Portanto, a verdadeira razão da grande mudança de atitude e gosto já existia há longos tempos, entre a classe rica, disposta a empregar seu capital ocioso em obras tumulárias no anseio de monumentalizar-se perante a comunidade. $^{28}$

Faziam-se presente nos primeiros espaços da morte brasileiros, de modo igualmente ostensivo, jazigos familiares pertencentes a famílias de origem imigrante que, de acordo com Motta,

\section{preferiram importar faustosos mausoléus [da Europa] [...]. Já sensibilidades mais afinadas com as tendências estéticas de vanguarda da época preferiram inovar discretamente no uso da arte funerária [...]. É oportuno lembrar que as tendências mais vanguardistas apareceriam com maior frequência somente no final da primeira metade do século XX29.}

A busca pelo poder e distinção sob forma de monumentos funerários tem sido uma constante em civilizações humanas. Faz-se evidente o cunho egóico de tal arquitetura que, edificada a partir de materiais perenes, pretende ser eterna. O caráter efêmero da memória de um indivíduo morto, portanto, deixa de existir, uma vez que tipologias arquitetônicas da morte e seus elementos assegurariam a constância de sua
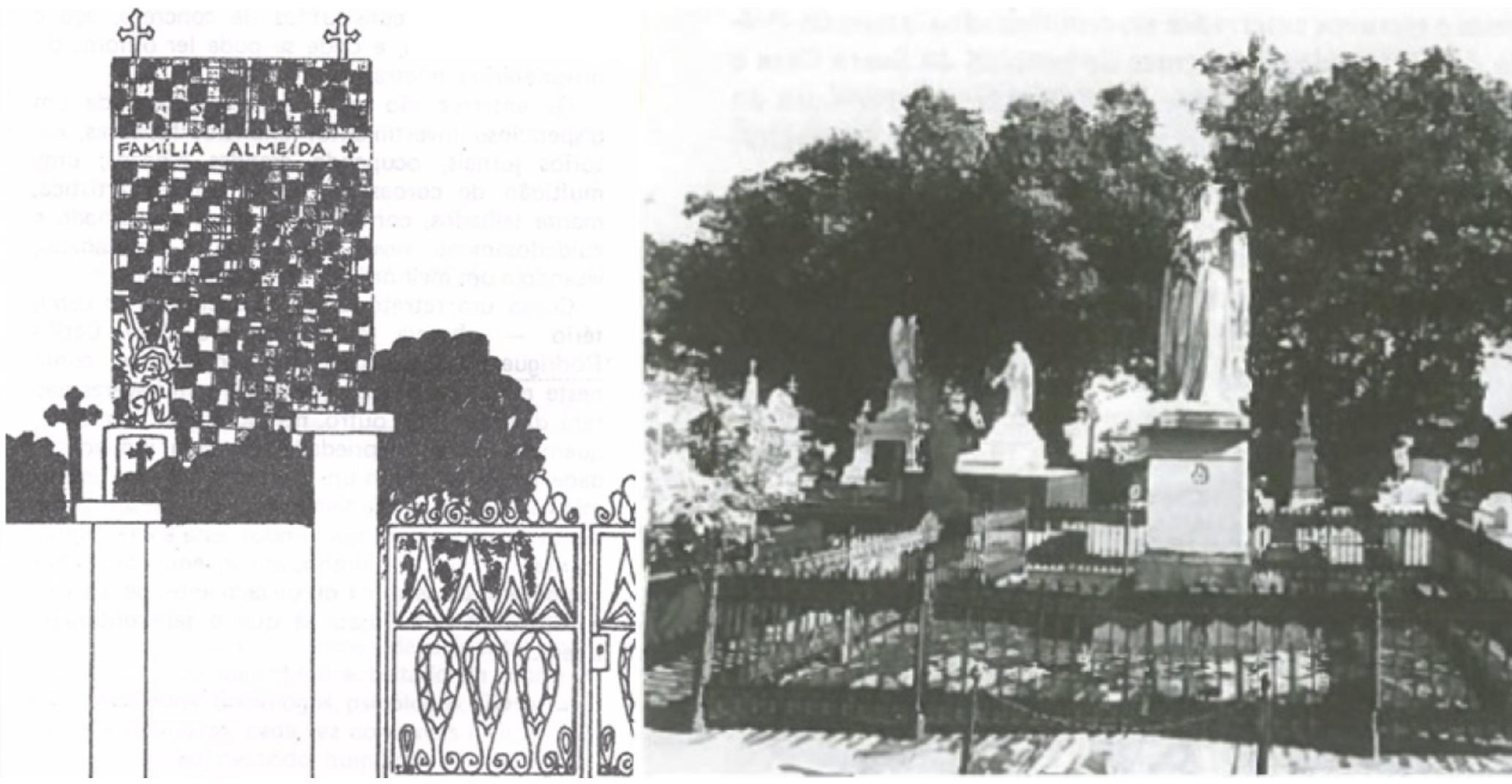

FIGURA 03: Representação de um grande mausoléu familiar: a estratificação de condutas funerárias, segundo Maranhão, é reflexo da existência de uma sociedade classista. FONTE: MARANHÃO [1985], 1998, p. 37.
FIGURA 04: Jazigo familiar do Barão de Cajaíba (1861): Reis sublinha a monumentalidade da sepultura. FONTE: REIS, 1991, p. 337. 
presença nos espaços, rememorando incansavelmente seu prestígio aos vivos e preservando a continuidade de seu poderio.

\section{Uma estética tumular autenticamente brasileira?}

A arquitetura adquire caráter vernacular na medida em que emprega materiais e elementos do próprio espaço circundante, o que the confere cunho eminentemente regionalista e particular. Como mostra Cymbalista a partir de sua pesquisa voltada aos cemitérios paulistas, a profusão estética em tais necrópoles conforma uma linguagem própria e dissociada de formas e instituições eruditas ${ }^{30}$, que estabelecem "conversas" entre si. Tais "diálogos" em cemitérios não surgem, no entanto, somente entre inscrições tumulares, mas entre mortos e vivos, alma e matéria, ser humano e fenômeno da morte, uma vez que no silêncio do espaço sepulcral os mortos se fazem presentes e a consciência da morte emerge. Violentamente o homem é colocado frente à "extrema ruptura que é a morte", como alcunha Motta31.
Ariès faz menção à "linguagem" dos túmulos, que seria uma "linguagem dos sonhos", porém o sentido é outro: entre os séculos XVI eXVIII procurou-se explicar certos fenômenos observados em cemitérios, oriundos de manipulações de restos mortais e de "um remanejamento constante, porém desigual e disjunto de cadáveres, de carnes e de ossadas nas igrejas de chão e nos cemitérios"; tratava-se de explosões de gases de decomposição, embora na época acreditavase que se devia a "obras do demônio":
O homem de hoje compreende
imediatamente quantos odores,
emanações e insalubridades essas
manipulações deviam acarretar. [...] É
forçoso reconhecer que o homem de
outrora se acomodou perfeitamente à
situação. [...] antes da intervenção dos
médicos, os rumores ouvidos nos
túmulos já intrigavam; hoje os
explicamos pelas explosões devidas aos gases da decomposição. De início foram interpretados como avisos sobrenaturais ${ }^{32}$.

30

0 autor aponta as instituições arquitetônicas eruditas como "excludentes" e "elitistas", que "se preocupam obsessivamente com a arquitetura stricto sensu, deixando de ver uma realidade essa arquitetura real e majoritária nas nossas cidades, feita não por arquitetos, mas por mestres de obra anônimos, os verdadeiros portadores da nossa cultura construtiva, distantes dos modelos importados e colonizados" (2002, p. 15-6).

31

À flor da pedra: formas tumulares e processos sociais nos cemitérios brasileiros, 2009, p. 25.

32

O homem diante da morte [1977], 2014, p. 638-40.

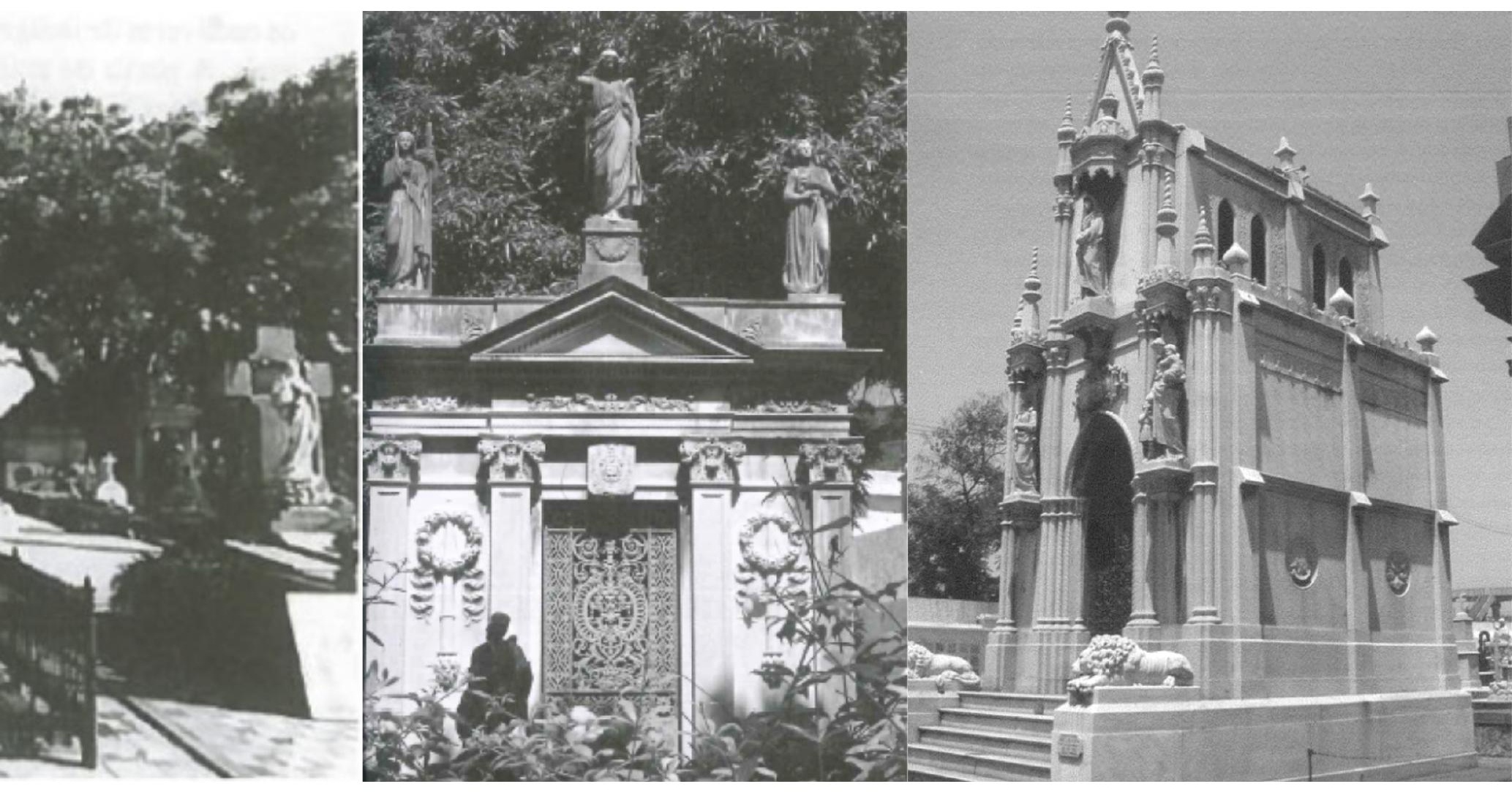

FIGURA 05: Jazigo familiar de João Gonçalves Raposo, no cemitério da Ordem III de N. S. do Carmo (RI). FONTE: MOTTA, 2009, p. 136.
FIGURA 06: Jazigo familiar no cemitério da Ordem Terceira dos Mínimos de São Francisco de Paula (Catumbi). FONTE: MOTTA, 2009, p. 67. 
FIGURA 07: Túmulo no cemitério de Rio Claro (SP). FONTE: CYMBALISTA, 2002, p. 106.
FIGURA 08: Túmulo no cemitério de Araras (SP). FONTE: CYMBALISTA, 2002, p. 106.
FIGURA 09: Túmulo no cemitério de Cravinhos (SP). FONTE: CYMBALISTA, 2002, p. 107.
FIGURA 10: Túmulo no cemitério de Casa

Branca (SP).

FONTE: CYMBALISTA, 2002, p. 107.
FIGURA 11: Túmulo no cemitério de Itu (SP). FONTE: CYMBALISTA, 2002, p. 108.
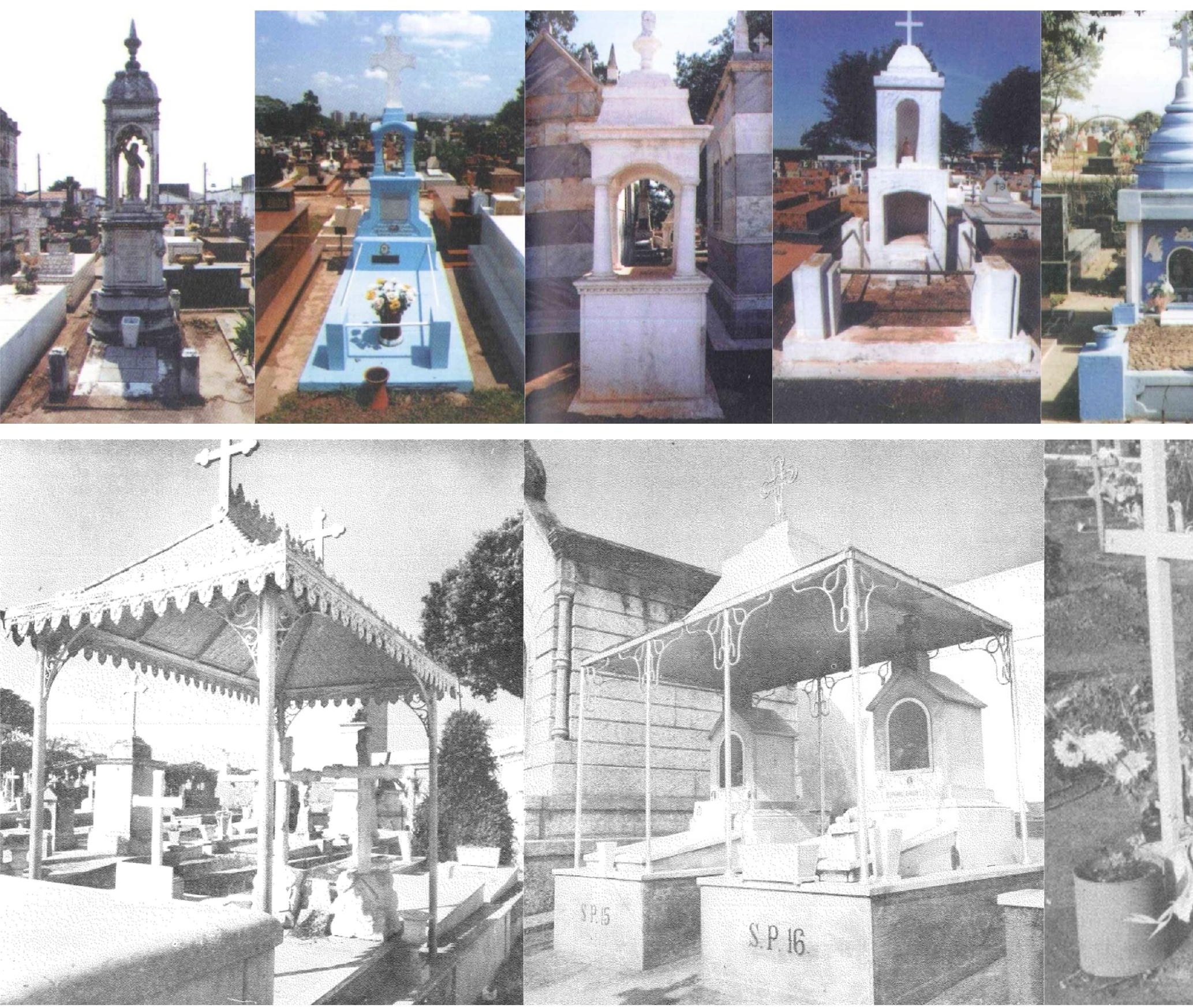

FIGURA 16: Túmulo com cobertura de metal (zinco) estampado. Cemitério S. Francisco Xavier, Rio de Janeiro. FONTE: VALLADARES, 1972, p. 1073.
FIGURA 17: Túmulo construído com tubos de ferro e cobertura de metal.

Cemitério do Catumbi, Rio de Janeiro.

FONTE: VALLADARES, 1972, p. 1073. 
FIGURA 12: Túmulo no cemitério de Brodósqui (SP).

FONTE: CYMBALISTA, 2002, p. 108.
FIGURA 13: Túmulo no cemitério de Ribeirão Preto (SP).

FONTE: CYMBALISTA, 2002, p. 109.
FIGURA 14: Túmulo no

cemitério de Cristais

Paulista (SP).

FONTE: CYMBALISTA,

2002, p. 113.
FIGURA 15: Túmulo no cemitério de Jaú (SP). FONTE: CYMBALISTA 2002, p. 113.
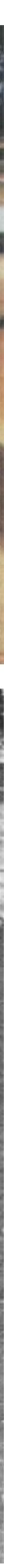

FIGURA 18: Túmulo construído a partir do aproveitamento de latas vazias.

Cemitério de S. Miguel e Almas, Goiás.

FONTE: VALLADARES, 1972, p. 1415.
FIGURA 19: Túmulo de operário construído a partir de arranjos de fragmentos de demolições.

Cemitério de N. S.a da Boa Morte, Espírito Santo.

FONTE: VALLADARES, 1972, p. 1389. 
FIGURA 20: Cruzes executadas em folha de ferro recortada. Cemitério de Vila Velha, Espírito Santo.

FONTE: VALLADARES, 1972, p. 1379.
FIGURA 21: Túmulo de granito fluminense e torre de chapas de metal. Trabalho de estaleiros locais.

Cemitério do Catumbi, Rio de Janeiro. FONTE: VALLADARES, 1972, p. 403.
FIGURA 22: Túmulo de granito apicoado. Cemitério Municipal de Petrópolis, Rio de Janeiro.

FONTE: VALLADARES, 1972, p. 627.

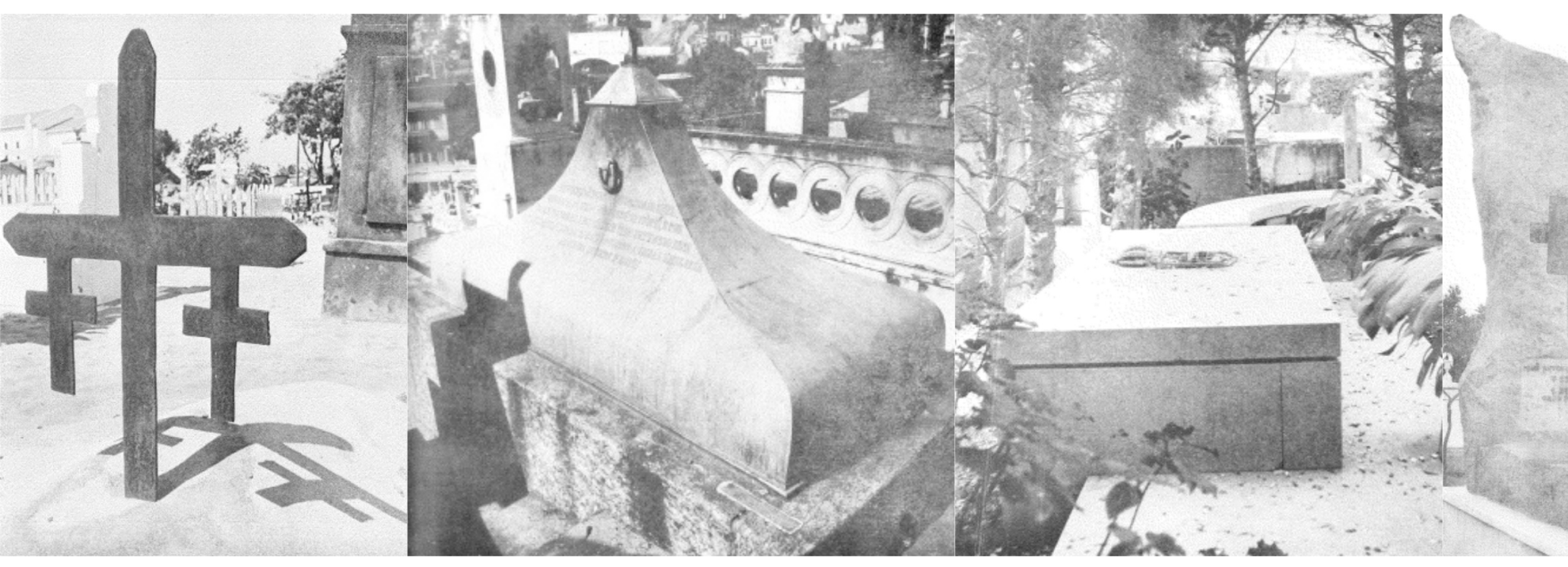

Segundo o autor, os médicos da época, preocupados com os ruídos e convencidos da relação entre cemitérios e epidemias, constrangiam-se pela incerteza das reais causas do fenômeno, que eram imediatamente atribuídos à esfera do sagrado ([1977], 2014, p. 639-41).

Christian Friedrich Garmann(1640-1708) foi médico, luterano e autor do livro De miraculis mortuorum. ARIÈS [1977], 2014, p. 639-41.

Cidades dos vivos: arquitetura e atitudes perante a morte nos cemitérios do Estado de São Paulo, 2002, p. 15-6.
A ideia é que, conforme Ariès, havia uma relação entre os ruídos dos túmulos, as emanações dos cemitérios e a frequente proliferação de epidemias na época, uma vez que a crepitação emanada era mais intensa durante as pestes. Deste modo, fenômenos a princípio inexplicáveis ${ }^{33}$ eram imediatamente atribuídos à esfera religiosa, visto que "a peste, o diabo e o cemitério constituem um triângulo de influências":

Fica-se impressionado pelo duplo caráter sagrado, reconhecido ao cemitério. De natureza diabólica, ele foi conquistado pela Igreja, mas pode voltar ao diabo; todavia é sagrado, e como tal, o homem não lhe pode pôr mãos profanas. Essa é a razão de se hesitar em deslocar cemitérios, afastá-los das cidades e até mesmo desinfetá-los com cal viva. [...] De modo geral, diz Garmann ${ }^{34}$, os mortos são sagrados: mortuos sacros. Como os altares e os templos, loca sacra, não se deve deslocá-los [non fas est movere], devese-Ihes reverentiae religio ${ }^{35}$.

Voltando ao tema da estética tumular brasileira, Cymbalista afirma que, no caso específico dos cemitérios interioranos de São Paulo, esta foi concebida pelos próprios pedreiros e mestres-deobras, que mobilizavam seus repertórios para construí- la: "independentes das instituições que elaboravam suas próprias sínteses, produzindo algo como um estilo popular brasileiro, distante das tradições vernaculares.

A tese do autor, no entanto, cai por terra quando ele mesmo observa que tal linguagem estética não era original, autônoma e oriunda dos próprios mestres de obra, mas uma mera tentativa de refletir e reinterpretar os túmulos da elite: "os túmulos dos mais ricos eram os modelos mais frequentes para as reinterpretações populares. [...] todos, sem exceção, diziam que os responsáveis pela forma final dos túmulos eram sempre as famílias dos mortos ${ }^{36 "}$.

Pode-se concluir, portanto, que, embora haja uma autêntica profusão de elementos funerários em espaços da morte brasileiros, esta não representa necessariamente uma linguagem estética própria e nacional, mas apenas a cópia de modelos dominantes na tentativa de aproximar os mortos "comuns" aos "ilustres"; assim, os menos abastados talvez obteriam, após a morte, o reconhecimento e a visibilidade que lhes foram negados em vida.

Conforme Valladares, o emprego de determinados materiais em edificações tumulares sempre pretende remeter ao status social do morto quando era vivo. Por essa razão, o uso de elementos tradicionais - como a 
FIGURA 23: Túmulo erigido em monobloco de granito fluminense imitando menir.

Cemitério de S. Francisco da

Penitência, Rio de Janeiro.

FONTE: VALLADARES, 1972, p. 389.
FIGURA 24: Túmulo revestido com seixos de barranco e cruz de metal recortado. Cemitério de Penedo, Alagoas. FONTE: VALLADARES, 1972, p. 1431.
FIGURA 25: Túmulo construído com blocos de minério de ferro das jazidas de Catas Altas. Cemitério Senhor do Bonfim, Belo Horizonte.

FONTE: VALLADARES, 1972, p. 388
FIGURA 26: Túmulo com inscrição em tampa de panela de alumínio amassada

Cemitério de Vila Vela, Espírito Santo. FONTE: VALLADARES, 1972, p. 1409.

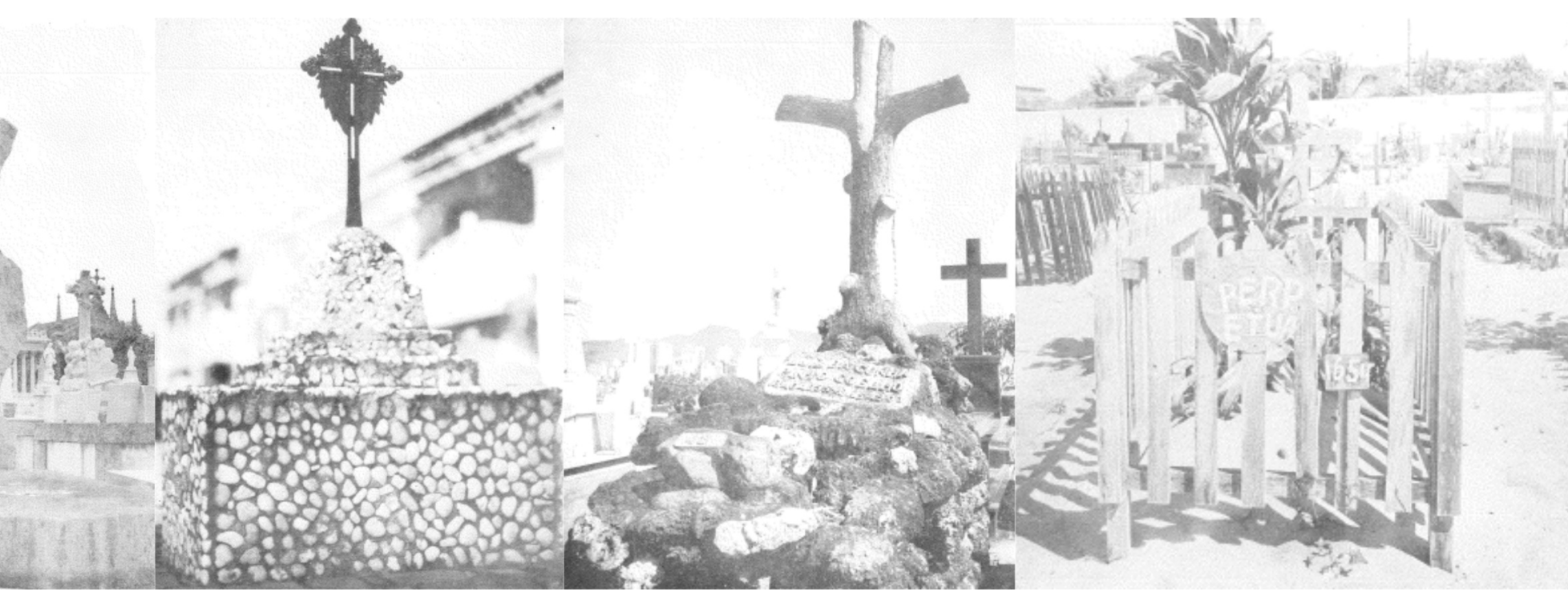

pedra de lioz importada; o mármore de Carrara e de outras procedências; o bronze e o ferro - representa poder e nobreza, uma vez que evidentemente apenas os mais abastados podiam empregá-los em seus jazigos:

$$
\begin{aligned}
& \text { Nas construções tumulárias das igrejas, } \\
& \text { os modelos e inscrições estavam } \\
& \text { submetidos a certos critérios e por tal } \\
& \text { razão nenhum usuário poderia } \\
& \text { empregar soluções impróprias. Com a } \\
& \text { secularização dos cemitérios e a } \\
& \text { liberdade da construção do túmulo ao } \\
& \text { gosto do proprietário, começaram a } \\
& \text { surgir [...] construções inusitadas }{ }^{37} \text {. }
\end{aligned}
$$

O caráter cemiterial vernacular já mencionado, expresso por meio do enaltecimento de materiais locais, faz-se presente na maior parte das necrópoles brasileiras ${ }^{38}$, o que incentiva ainda mais a conformação de paisagens fúnebres heterogêneas e desvinculadas de quaisquer ideologias dominantes:

\footnotetext{
É um engano pensar-se que a criação artística só tem validade quando deglutida e digerida por uma elite. Ela é bem mais autêntica quando produzida e consumida no âmbito de sua motivação, naquela espontânea aventura da arte popular, pouco antes de ser deglutida e digerida pela arte erudita sempre capaz
}

de transformá-la em novos movimentos de denominação sofisticada $[. . .]^{39}$.

O fenômeno da transfiguração estética tumular não é observado, no entanto, em jazigos de imigrantes que, por tradição, costumavam reproduzir no túmulo feições semelhantes às da habitação, denotando uma espécie de continuidade entre espaços da vida e da morte. Obviamente tampouco é verificado nos túmulos pertencentes aos mais abastados, que se utilizavam de todos os recursos arquitetônicos na busca pela distinção e monumentalidade.

Por fim, a título de exemplo de profusão da morte eminentemente brasileira, merece ser mencionado o cemitério de S. Francisco de Paula (Rio de Janeiro) que, segundo Valladares, já configurou espaço exclusivo para a elite carioca e um "mostruário do gosto da pequena burguesia”; porém, atualmente,

milhares de sepulturas vibram no colorido de azulejos sanitários de todas as cores, floridos de matéria plástica e em grande número enfeitados de lâmpadas miudinhas, formando cruzes, rosários, resplendores, ou modestas lamparinas num serviço de instalação elétrica [...] com os dizeres: LUZ ETERNA. INSTALAÇÃO GARANTIDA NA SEPULTURA. TRATAR NA SECRETARIA ${ }^{40}$
37

Arte e sociedade nos cemitérios brasileiros, 1972, p. 449.

38

VALLADARES, 1972, p. 453.

39

Idem, p. 451.

40

Arte e sociedade nos cemitérios brasileiros, 1972, p. 450. 


\section{Referências bibliográficas}

AMORA, A. S. [1967]. O Romantismo: 1833-1838/1878-1881. $5^{\text {a }}$ ed. São Paulo: Cultrix, 1977. $356 \mathrm{p}$.

ARIÈS, P. [1977]. O homem diante da morte. Tradução de Luiza Ribeiro. São Paulo: Editora Unesp, 2014. 837 p.

AZEVEDO, A. [1880]. Uma lágrima de mulher. $4^{\mathrm{a}}$ ed. São Paulo: Editora Martin Claret, 2004. 157 p. (Coleção A obra-prima de cada autor; n. 132)

CITELLI, A. [1993]. Romantismo. $3^{\text {a }}$ ed. São Paulo: Editora Ática, 1993. 96 p. (Série Princípios; n. 78)

CYMBALISTA, R. [2002]. Cidades dos vivos: arquitetura e atitudes perante a morte nos cemitérios do Estado de São Paulo. São Paulo: Annablume: Fapesp, 2002. 210 p.

JUNG, C. G. et al. [1964]. O homem e seus símbolos. Tradução de Maria Lúcia Pinho. Rio de Janeiro: Nova Fronteira, 2002.316 p. (22 $2^{\mathrm{a}}$ impressão)

KOVÁCS, M. J. [1992]. Morte e desenvolvimento humano. $3^{\text {a }}$ ed. São Paulo: Casa do Psicólogo, 1992. $243 p$.
MARANHÃO, J. L. de S. [1985]. O que é morte. $4^{\mathrm{a}}$ ed. São Paulo: Brasiliense, 1998. 77 p. (Coleção primeiros passos, n. 150)

MOTTA, A. [2009]. À flor da pedra: formas tumulares e processos sociais nos cemitérios brasileiros. Recife: Fundação Joaquim Nabuco, Editora Massangana, 2009. 202 p.

REIS, J. J. [1991]. A morte é uma festa: ritos fúnebres e revolta popular no Brasil do século XIX. São Paulo: Companhia das Letras, 1991 (6 ${ }^{\mathrm{a}}$ reimpressão: 2012). $357 \mathrm{p}$.

SANTOS, S. J. dos; FREITAS, A. [2012]. A arte cemiterial como fator de distinção e eternização do status social no Cemitério São Francisco de Paula. O Mosaico: Revista de Pesquisa em Artes, Curitiba, n. 7, p. 31-45, jan./jun., 2012.

VALLADARES, C. do P. [1972]. Arte e sociedade nos cemitérios brasileiros. Rio de Janeiro: Conselho Federal de Cultura, 1972. 1487 p. 